DOI: $10.22363 / 2312-9220-2021-26-4-689-696$

УДК 659.4

Research article / Научная статья

\title{
New Strategies of Omni-Mediatization of the Public Policy in Kazakhstan
}

\author{
Mariyamgul M. Kussainova \\ Institute of Public Policy of Nur Otan party, \\ 12/1 Dinmukhamed Kunaev St, Nur-Sultan, 010000, Republic of Kazakhstan \\ marika_91kz@mail.com
}

\begin{abstract}
In the context of the accelerated development of new media and the growth of e-democracy, the mediatization of Kazakhstani politics is entering a new digital-driven stage of development. The author's approach relevance lies in studying the modern digitaldriven strategy of Kazakhstani political communication and identifying methods of influence of political parties on the electorate, manipulative media forms on certain segments of the electorate from the opposition. The article presents an analysis of the main strategic resources of the politics mediatization and of their impact. Moreover, it reveals the influence tendencies of the political mediatization, the political communication in society and with party stakeholders. The author attempts to analyze the methods and formats of transmedia storytelling in the social networks on the Internet for the political leaders communication shaping, social and political dialogue building. The research material included the election campaigns of parliamentary and unregistered parties texts in Kazakhstani social media, the posts / publications on social networks during the first ever primaries in the country's history and the parliamentary elections of 2019 and 2021.
\end{abstract}

Keywords: social policy, new media, elections, political brand, transmedia storytelling, opposition, stratum, primaries, mediatization of politics

Conflicts of interest. The authors declare that there is no conflict of interest.

Article history: submitted: March 10, 2021; accepted: May 17, 2021.

For citation: Kussainova, M.M. (2021). New strategies of omni-mediatization of the public policy in Kazakhstan. RUDN Journal of Studies in Literature and Journalism, 26(4), 689-696. doi: 10.22363/2312-9220-2021-26-4-689-696 


\title{
Новые стратегии омнимедиатизации общественной политики в Казахстане
}

\author{
М.М. Кусаинова \\ Институт общественной политики, \\ Республика Казахстан, 010000, Нур-Султан, ул. Динмухаммеда Кунаева, 12/1 \\ $\triangle$ marika_91kz@mail.com
}

\begin{abstract}
Аннотация. В контексте ускоренного развития новых медиа и роста электронной демократии медиатизация казахстанской политики выходит на новый этап развития, основанный на цифровых технологиях. Актуальность авторского подхода заключается в изучении современной цифровой стратегии казахстанской политической коммуникации и выявлении методов воздействия политических партий на электорат, манипулятивных медиаформ на отдельные сегменты электората со стороны оппозиции. Представлен анализ основных стратегических ресурсов медиатизации политики и их влияния. Выявлены тенденции влияния медиатизации на политическую жизнь общества и работу со стейкхолдерами партий. Сделаны попытки проанализировать методы и форматы трансмедийного повествования в социальных сетях Интернета для формирования коммуникации политических лидеров, построения социального и политического диалога. В качестве материалов исследования использованы тексты избирательных кампаний парламентских и незарегистрированных партий в казахстанских социальных сетях, посты / публикации в социальных сетях во время первых в истории страны праймериз и парламентских выборов 2019 и 2021 гг.
\end{abstract}

Ключевые слова: социальная политика, новые медиа, выборы, трансмедийный сторителлинг, оппозиция, страта, праймериз, медиатизация политики

Заявление о конфликте интересов. Авторы заявляют об отсутствии конфликта интересов.

История статьи: поступила в редакцию - 25 марта 2021 г., принята к публикации - 17 мая 2021 г.

Для цитирования: Kussainova M.M. New strategies of omni-mediatization of the public policy in Kazakhstan // Вестник Российского университета дружбы народов. Серия: Литературоведение. Журналистика. 2021. Т. 26. № 4. С. 689-696. doi: 10.22363/ 2312-9220-2021-26-4-689-696

\section{Introduction}

In Kazakstan, last years the political life is changing dramatically. But the growing activity of political parties are not completed with relevant media strategies, tools and effects.

On the background of the changing role of the state in the context of political transformation in Kazakhstan, new subjects of social policy are becoming more active. Political parties, civil movements and NGOs are among them and they create 
a separate category of media communication. In order to manage stakeholder relations effectively, the emphasis is placed on the systematic identification, analysis and planning of communications, negotiation and influence on stakeholders on social networks such as Facebook, YouTube, Instagram and Telegram.

Thus, the research question is: What are the main features of mediatization of public policy in Kazakhstan?

The methodological basis includes modern theories in the spheres of political science, communication studies, mediatization, journalism and PR. In order to realize the set tasks, the narratives received during the monitoring of social networks of parties and individual candidates in the pre/post-election period with open access, were used. Methods of monitoring and analysis of social media using the automated systems Alem Media Monitoring and Brand Analytics, content analysis of the websites of political parties and unregistered movements were applied.

The research material included the election campaigns of parliamentary and unregistered parties texts in Kazakhstani social media, the posts / publications on social networks during the first ever primaries in the country's history and the parliamentary elections of 2019 and 2021.

\section{Mediatization of politics: Social media impact}

According to the Kazakhstani political scientist R. Nurtazina, along with the social relevance of the semantic information, the evaluative information is substantial as well. It is the evaluative information that contributes to the formation of public opinion. And this is already a lever used by the political forces of society to achieve their goals [1].

The definition of the mediatization of politics was introduced for the first time by the Swedish scholar K. Asp. He has defined it as a process of political news broadcast by the mass media, focusing on the transformation of politics under the peculiarities of the mass media. The mediatization of politics in political communication studies means a set of interconnected information and communication phenomena and processes occurring both within the political space and in the external environment, through public presentations and frames of political and public meanings [2].

David L. Swanson and Dan Nimmo define the political communication as "the strategic use of communication to influence public knowledge, belief and action on political issues" [3]. They emphasize the strategic nature of political communication by highlighting the role of persuasion in political discourse. Brian McNair provides a similar definition when he writes that the political communication is "a purposeful communication about politics". In McNair's view, it also includes all those aspects that develop "political identity" or "image" [4].

With the development of social media, the role of the politics mediatization as an informational and strategic resource has increased dramatically. The fact 
that we are entering the era of the "omni-mediatization" is evidenced by the works of the American media researcher S. Livingstone [5].

Social networks allow political parties and movements to manage voters proactively: first, by defining the goal of interaction, and only then by selecting the tools and format of communication for it. In turn, for society, along with the advantages (prompt interaction, possibility of dialogue and openness on the part of political structures), there are communication risks that complicate and destroy. Firstly, parties use anonymous Telegram channels (given their brevity and efficiency), which can be calculated by comparing the content and frequency of publications, they have two main purposes: 1) to foresee the audience's reaction to any action and 2) to manipulate information by referring reliable sources and public opinion leaders. The trend of political communications on Facebook and YouTube in terms of influencing the electorate and the audience as a whole has become transmedia storytelling, which allows integrating systems of rational and sensory influence.

Secondly, the social networks have changed politics, because it has given political polities and opposition movements a direct means of communicating to their constituents and people - the opportunity to communicate directly with politicians. This kind of informality may lead to information errors for the reason that it is not subject to the "fact-checking processes as institutional journalism" [6]. A relevant example is the civil case filed by the first deputy chairman of Nur Otan Bauyrzhan Baibek against activists Zhanbolat Mamai and Inge Imanbayeva. In the lawsuit, Baibek asked to recognize the information as untrue, discrediting his honor, dignity and business reputation (the activists accused B. Baibek of corruption and published a series of films with interactive storytelling on social networks).

\section{Deep mediatization of politics: Towards transmedia storytelling}

Nowadays, mediatization of politics became more and more voter-centered. The voter, through the points of contact, determines to what extent a given party is "his own", whether it reflects his views, whether he will be able to declare his position through belonging to this organization.

Among the most effective tools of media communication with voters in politics is storytelling. According to D. Boyle, the main task of storytelling in political discourse is to explain the situation, make it easy to understand and, consequently, make it believable. Thus, "every candidate in the 2008 presidential race appears as the hero of at least one narrative tied to one of the nation's key issues: McCain and the noble warrior saga, Hillary Clinton and the story of the American woman, Obama and the tale of the two races" [7].

In December 2020, in Kazakhstan, for the first time intra-party elections the primaries were held. These elections demonstrated that the candidates could not build a strong and relevant to modern communication requirements image of their organization, establish a strong long-term connection with their voters 
through self-identification, which is best built by the use of storytelling method in communications.

In the era of social media the political discourse is changed. The traditional storytelling does not works. Kazakhstani politician and public figure Amirzhan Kossanov during the campaign for president of Kazakhstan in 2019 used similar to American presidential election tactics. His trick was the profession of a journalist, i.e. the role of a fighter for the truth. A. Kossanov used the model of the "closeness to the people - a person who comes from the people". Social network users subsequently accused him of false opposition.

Since 2011 s, in the times of deep mediatization storytelling became more complex. Transmedia storytelling is a technique of telling a story across multiple platforms and formats, using modern digital technology.

S. Emerson quotes H. Jenkins in "The Great Examples of Multi-Platform Storytelling" that we live in transmedia, a globally connected world where we use multiple platforms to connect and communicate [8]. Today, transmedia storytelling is a theory that is finally beginning to find practical success.

The transmedia storytelling allows the interpretation of a story from an individual perspective, opening the way for personalized reflection. The new model of experiential transmedia storytelling is based on six fundamental qualities of the digital environment: interactivity; immersion [9]; multisensory presentation; algorithm and information management; first-person perspective; natural user interface.

An expert in the field of communications I. Kiriya believes that the processes of mediatization of socio-political movements and civic activism, in particular, occurring through the use of transmedia tools, are of great importance [10]. While the state authority establishment is reluctant to use transmedia in an effort to avoid the effects of participatory democracy, the transmedia storytelling is becoming the main form of engaging audiences in political and social transformation.

In Russia, the projects of Alexei Navalny and the art group "Partizaning" are the vivid examples of transmedia activism. In Kazakhstani practice, the opposetionists Zh. Mamai from the Democratic Party of Kazakhstan and the leader of the banned (unregistered) party in Kazakhstan M. Ablyazov's Democratic Choice of Kazakhstan are using similar models of transmedia storytelling. Unlike the parliamentary parties "Ak Zhol", "NPK" and "Auyl", which have election programs and specific tasks for implementation, as well as direction and electorate, the opposition uses other channels and forms of influence (manipulation) through social networks. The peculiarity of the work of two representatives is that one (Zh. Mamai) communicates with the audience while in Kazakhstan, and the second (M. Ablyazov) from France. Both candidates use the social justice model of transmedia storytelling. The specificity of the dialogue with the audience according to this model is to unite people through social networks (Facebook, Instagram and Telegram channels), since congresses and gatherings easily may turn into meetings and they are prohibited by law. The storyline and unfolding of the story depend on the communication channel and the ultimate goal of 
influencing the audience. For example, Zh. Mamai (head of story: he is a positive hero "opposition journalist and participant in the "December events", but with dubious initiatives. For anti-government actions and rallies, he does not receive a prison sentence in comparison with other activists) who raises acute social issues throughout his career, voices the most painful problems: bank credit, Chinese expansion, the land of Kazakhstan, the state language, etc., manipulating the consciousness of the average class of Kazakhstanis.

The same model is used by M. Ablyazov, (head of the story: he is a negative character "fugitive banker and ex-politician", but pursued by the law enforcement agencies of the Republic of Kazakhstan and with loud revelations of Kazakhstani politicians) he puts the construction of Utopia, the realism of which is added by mixed facts and fakes about joint labor activities with the First President of the Republic of Kazakhstan N. Nazarbayev. As a manipulative tool, Ablyazov tells stories about a tough career, difficulties, desires to serve the country, its prosperity, to provide a better life for the people, discrediting Elbasy, allegedly hindering his efforts. People on social networks unite in groups based on a common desire to live in Utopia, not paying attention to the fact that information is presented in the form of rumors that are transmitted in word-of-mouth through the Telegram channel "Uzyn Kulak" ("Long Ear" in translation from Kazakh), blindly following Ablyazov's policy and identifying themselves with him, trying on his role and events.

Both politicians have an impressive number of followers and friends on social networks (hidden in the settings), so the speed of distribution, audience response and reach is high.

The trend of transmedia storytelling is the visual stories in the format of investigative films. The plot is based on the conflict of good and evil interests. The acting authorities play the role of the evil, and an opposition activist, standing up for justice and trying to open people's eyes to the glaring injustice, plays the role of the good. The culminating moment is the "unmasking" scene, the presentation of archival documents about illegal real estate or parallel business, as well as the property or financial condition of close relatives. Fragmentary videos are published on Facebook, gaining popularity and comments, generating a new format of stories already in the official mass media. As a rule, official denials began to take place after the scandalous film by Zh. Mamai about the first deputy chairman of the "Nur Otan" party B. Baibek [11].

The author of "Media Communication. An Introduction to Theory and Process", James Watson emphasizes that regardless of whether the information is factual or fictional, it must be assembled into a narration because when stories are told, regardless of their format and genre, meanings are created and conveyed [12].

The past parliamentary elections of 2021 , as well as the primaries that preceded them, revealed an important problem: the vast majority of political organizations begin their activities six months before the political campaign, when there is already a fierce competition. This is a result of the fact that a party 
strategy is not established. As a result, we see a lack of solid organizations that know their voters and are familiar to them. A similar situation occurred in the parliamentary elections of January 10, 2021, when in a short time "revived" or reformatted the direction of several years work of dormant parties ("Birlik" and "KNPK"), and also returned "to the stage" of ex-politicians. Identical without "self-identity" organizations brought only informational noise in voter's head, leaving him in uncertainty.

As a consequence, in Kazakhstan there is an insufficiently developed political communication, the absence of a systematic dialogue between parties and voters, as a result, a surrogate opposition is growing, digital democracy risks becoming uncontrollable, social networks are becoming a tool for manipulating public consciousness. A problematic feature in the differentiation of political organizations is their one-sided anti-positioning of the existing power. In practice, organizations do not have another articulated advantage or message that would be relevant and understandable to potential voters.

Thus, as the main characteristics of transmedia storytelling in politics should be considered the obligatory presence of a story on a current topic (conflict of interest) and the interpretation of story through the prism of the author's perception.

\section{Conclusion}

In Kazakhstan, omni-mediatization became the core strategy for political parties and opposition movements. The transmedia storytelling should be recognized as a promising direction of their strategies. The main advantages of this communication technology are that it becomes possible not only to create the effect of "self-identification" with his party and participation of the voter, but also to involve them in active interaction, to create a both real and virtual reality that combines online and offline contact of parties and society. Politics becomes more open, accessible and "close" for each of the social groups.

The social media, coupled with the competent use of various storytelling models, play a key role in mobilizing voters, as stories appeal to the values and emotions of their target audiences, achieving a lasting emotional connection between them.

The transmedia storytelling as a tool in social and political communication, which is based on the principle of influence, audience mobilization and manipulation both in virtual reality and in the space of public politics in the form of opposition protest activities. However, the storytelling method in Kazakhstani public politic is underdeveloped or applied incorrectly, which significantly hinders party branding and quality management.

In terms of communication risks, social media in Kazakhstan fosters an uncontrolled flow of information for voters and the growth of populist statements by political parties. Unregistered movements, in the absence of official party programs, use storytelling to manipulate, implicitly shaping the values, norms and behavioral patterns of citizens. 
Thus, the main features of mediatization of public policy in Kazakhstan are paternalistic format of interaction and politics through social media (protection of society from surrogate opposition), activation of e-democracy and the growth of digital platforms for interaction between political parties and the electorate, taking into account the specifics of the content.

\section{References / Библиографический список}

[1] Nurtazina, R.A (2014). Republic of Kazakhstan: media and politics. P. 104-118. Almaty. (In Russ.)

Нуртазина Р.A. Республика Казахстан: СМИ и политика. Алматы, 2014. С. 104-118.

[2] Gribovod, E.G. (2016). Mediatization of Politics as a Strategic Resource of Political Communications. Krasnoyarsk Science, 6(39). (In Russ.)

Грибовод Е.Г. Медиатизация политики как стратегический ресурс политических коммуникаций // Наука Красноярья. 2016. № 6(39).

[3] Swanson, D. \& Nimmo, D. (1990). New Directions in Political Communication: A Resource Book.

[4] Brian, McNair. (2017). AN Introduction to Political Communication.

[5] Livingstone, S. (2009). On the mediation of everything. Journal of Communication 59(1), 1-18.

[6] Graber, Doris A., \& Dunaway, Joanna (2017). Media and American Politics. CQ Press.

[7] Boyle, D. In Search of a Political Narrative. Retrieved February 12, 2021, from http://davidboyle.co.uk/ politics/narrative.html.

[8] Jenkins, H. (2006). Convergence Culture: Where Old and New Media Collide. NY.: New York University Press.

[9] Carey, D.J. (1989). Communication as culture. NY.; London: Routledge.

[10] Kiriya, I.V. (2021). Mediatization of social institutions, communities and everyday life. Retrieved March 27, 2021, from https://www.hse.ru/org/projects/205017353

[11] Navalny's method: Zhanbolat Mamay vs. Bauyrzhan Baybek. Retrieved May 8, 2021, https://www.youtube.com/watch?v=GnZ955q_b9w

[12] Watson, J. Media communication. An Introduction to Theory and Process (pp. 130-146).

\section{Bio note:}

Mariyamgul M. Kussainova, $\mathrm{PhD}$, Chief Expert of the Institute of Public Policy. ORCID: 0000-0002-9082-1528, e-mail:marika_91kz@mail.ru.

\section{Сведения об авторе:}

Кусаинова Мариямгуль Муратовна, $\mathrm{PhD}$, главный эксперт Института общественной политики. ORCID: 0000-0002-9082-1528, e-mail: marika_91kz@mail.ru. 